\title{
Use of habitat and foraging time by females of Eptesicus nilssonii (Chiroptera, Vespertilionidae)
}

\author{
Dmitriy G. Smirnov*, Vadim A. Bezrukov \& Nailya M. Kurmaeva
}

ABSTRACT. Characteristic features of summer habitat and foraging time used by female E. nilssonii of differing reproductive status have been investigated. The research was carried out in the north of Samarskaya Luka in May and July 2012-2018. Sixteen bats were captured and tagged with transmitters. Research revealed that tree hollows serve as main roosts for bats. Regular roost switching is characteristic for pregnant and post-lactating female colonies, while lactating females utilize the same roost for nearly the entire lactation period. Evening emergence of bats is highly light dependent and occurs 40 minutes after sunset on average. Female home range size is similar in spring and summer, and averages 430.7 and 401.8 ha, respectively. Regardless of the season, their main foraging sites are forest edges, clearings, and spaces along the vertical tree and shrubbery vegetation structure of the riverbank area. Pregnant and post-lactating females not caring for offspring exhibit similar duration of nocturnal activity. Lactating females forage less and in phases. In late spring, females often hunt in places located over $3 \mathrm{~km}$ away from daytime roosts, while in summer they usually forage within $1 \mathrm{~km}$ of the roost. The revealed differences in behavior of pregnant, lactating, and post-lactating females are discussed in relation to insect resources and the energy costs of foraging and feeding non-flying offsprings.

How to cite this article: Smirnov D.G., Bezrukov V.A., Kurmaeva N.M. 2021. Use of habitat and foraging time by females of Eptesicus nilssonii (Chiroptera, Vespertilionidae) // Russian J. Theriol. Vol.20. No.1. P.1-10. doi: 10.15298/rusjtheriol.20.1.01.

KEY WORDS: bats, Chiroptera, Eptesicus nilssonii, home range, habitat use, radio-tracking.

Dmitriy G. Smirnov [eptesicus@mail.ru], Penza State University, Krasnaya str. 40, Penza 440026, Russia; Vadim A. Bezrukov,[nigelous@rambler.ru],Penza State University, Krasnaya str. 40,Penza 440026, Russia; Nailya M. Kurmaeva [nmk74d@yandex.ru], Penza State University, Krasnaya str. 40, Penza 440026, Russia.

\section{Использование пространства и кормового времени самками Eptesicus nilssonii (Chiroptera, Vespertilionidae)}

\author{
Д.Г. Смирнов*, В.А. Безруков, Н.М. Курмаева
}

РЕЗЮМЕ. Изучали характер использования пространства летних мест обитания и кормового времени самками E. nilssonii, находящихся в разных репродуктивных состояниях. Работы проводили в мае и июле 2012-2018 гг. на севере Самарской Луки. Было отловлено и помечено радиопередатчиками 16 особей. Выявлено, что основными убежищами животным служат дупла деревьев. Регулярная смена мест дневок свойственна колониям беременных и постлактирующих самок, тогда как кормящие используют одно убежище почти на протяжении всего периода лактации. Вечерний вылет происходит в среднем через 40 мин. после захода солнца и сильно зависит от освещенности. Размеры участков обитания у самок весной и летом не отличались и в среднем составляли 430.7 и 401.8 га, соответственно. Независимо от сезона основными их кормовыми территориями являются лесные опушки, поляны и пространства вдоль вертикальных элементов древесно-кустарниковой растительности береговой зоны. У необремененных заботой о потомстве беременных и постлактирующих самок продолжительность ночной активности сходная. У лактирующих самок кормовая активность заметно меньше и имеет многофазный характер. В конце весны самки чаще охотятся в местах, расположенных на расстоянии более 3 км от дневных убежищ, тогда как летом - редко улетают кормиться дальше 1 км. Выявленные различия обсуждались в связи с обилия кормовых ресурсов в среде и энергетическими затратами на поиск пищи и выкармливания нелетных детенышей.

КЛЮЧЕВЫЕ СЛОВА: рукокрылые, Chiroptera, Eptesicus nilssonii, участок обитания, использование пространства, телеметрия.

* Corresponding author 


\section{Introduction}

Characteristic features of habitat use and foraging time are the key factors of vital activity and stability of any population (Shultz et al., 1999; Kusch et al., 2004; Montgomery \& Roloff, 2013). These specific factors are important in effective management and in developing a common conservation strategy, especially for with small population size and vulnerable species or for individual populations that are likely to become endangered or reduced due to environmental changes.

Territorial distribution preference and duration of stay of any species at a specific habitat usually reflect the presence of a key resource, such as food source or suitable roosting (Allyson \& Harris, 1996; Shultz et al., 1999; Wiens, 2001; Haupt et al., 2006). Such factors are extremely important because they can have a significant impact on how behavior and population density depend on natural and man-made changes. Therefore, for conservation purposes it is important to evaluate the adaptability of the species to different habitats.

Summer habitats of bats are limited to areas where foraging sites and a range of actively used and potential roosts are concentrated. The home range size of bats may vary depending on the sex, age, reproductive status, colony size, and environmental biotopic characteristics (Burt, 1943; Hamilton \& Watt, 1970; Jones et al., 1995; Henry et al., 2002). In particular, the energy demands of pregnant and lactating females may limit their home ranges (Henry et al., 2002). Adult females are also able to change their behavior models and daily time use depending on energy demands at different stages of the reproductive cycle (Speakman \& Thomas, 2003). In some species of bats, pregnant females reduce the torpid period to decrease the effect of low temperatures on the rate of embryo development (Racey, 1973; Racey \& Swift, 1981; Dietz \& Kalko, 2007). At the same time, increase in foraging time can compensate for energy losses due to fetal development (Barclay, 1989; Rydell, 1993a; Catto et al., 1995; Grinevitch et al., 1995; Shiel et al., 1999; Dietz \& Kalko, 2007). Postpartum females incur a significant energy cost from lactation (Racey \& Speakman, 1987; Wilde et al., 1995; McLean \& Speakman, 1997), but the need to feed offspring limits their ability to compensate for these losses with foraging (Henry et al., 2002; Smirnov et al., 2017c). At the end of lactation, foraging time is expected to increase.

The purpose of the work was to study habitat use, home-range and foraging time in female Eptesicus nilssonii (Keyserling \& Blasius, 1839) of different reproductive status. This species is widespread in the Palearctic. In the European part of Russia, it occurs sporadically (Ilyin et al., 2002a), inhabiting coniferous, mixed, and partially deciduous forests of the northern and central regions.

\section{Material and methods}

Research area - The study was conducted in the most elevated part of Samarskaya Luka (Samara Region,
Russia), called the Zhiguli Mountains (N 53.4450$\left.53.4171^{\circ}, \mathrm{E} 49.9290-49.9062^{\circ}\right)$. The northern mountain slopes drop very abruptly down to the Volga River, forming a system of mountain ranges with pine forests and gorge-like ravines overgrown with deciduous forests. The highest tops are 300-380 meters. As a result of extensively distributed karst, there are no water bodies in the territory. The climate is temperate continental, milder due to the Volga River valley, which covered the entire territory with by a wide bend.

Potential summer habitats include predominantly maple and linden forests with numerous clearings along the edges, the above-water surface of the Volga River, and populated places with streets located along the riverbank.

Bat capture and tagging - To find roosts of bats and to identify the degree of their activity and habitat use, we captured and tagged 16 adult females in May and July 2012-2018 (Tab. 1). The bats were captured using mist nets at night (Smirnov et al., 2017b). After measuring the main morphological parameters (forearm length, body weight), the bats were tagged with $0.42 \mathrm{~g}$ TXA-001G transmitters (Telenax, Mexico). The relative weight of transmitters varied from $4.8 \%$ to $3.4 \%$ of the animal body mass, which is below the established threshold recommended for radio-tracking of bats (Aldridge et al., 1988). The transmitters were attached to the back between the shoulder blades using surgical adhesive. The tagged bats were kept until dawn and released to the location of their capture. Gestation (Gest.) was detected by palpation, and lactating (Lact.) and post-lactating (Postl.) status was determined by enlarged nipples surrounded by bare skin and milk secretion. All bats tagged with transmitters were members of maternity colonies.

Radio-tracking and field observations — Tagged bats were tracked during the whole period of their activity by two teams using Yagi antennas and scanning receivers. The first group stayed in the roosting area, choosing the highest terrain point for direction finding, while the second group followed the signal on foot or by transport (car, powerboat). Both teams were able to perform simultaneous triangulation, and the exchange of information was carried out using walkie-talkies. The trajectory of movement and roosts of tagged bats were recorded using map charts and a Garmin Oregon 400t GPS navigator. Decryption and spatial information processing were implemented with Quantum GIS v.3.4.5 software.

Transmitter signal tonality and loudness level in the research area were tested in various conditions immediately after its activation and before attaching to the bat body. Therefore, we were aware of possible limitations that could be caused by non-uniform signal propagation, for example, due to the impact of terrain heterogeneity and source distance from the point of direction finding. To estimate the distance from the observer to the tagged bat, a previously developed technique was used (Smirnov et al., 2013).

A Pettersson D-240x ultrasound detector (Pettersson Elektronik AB, Sweden) with time-expansion factor of 10 and memory size of 1.7 seconds was used as a tool to determine presence of conspecifics and other species 
Table 1. Radio-tracking data of 16 females Eptesicus nilssonii bats in May and July 2012-2018.

\begin{tabular}{|c|c|c|c|c|c|}
\hline Code & Tracking period & Body mass (g) & Reproductive status & Home range (ha) & $\begin{array}{c}\text { Maximum distance } \\
\text { from the roost (m) }\end{array}$ \\
\hline 1F & May 16-22, 2013 & 11.5 & Gest. & 422.790 & 5863 \\
\hline 2F & May 13-21,2014 & 8.7 & undefined & 336.407 & 5068 \\
\hline 3F & May 15-23, 2014 & 10.2 & undefined & 259.256 & 2536 \\
\hline 4F & May 18-24, 2014 & 10.4 & Gest. & 221.544 & 4357 \\
\hline 5F & May 21-26, 2015 & 10.3 & Gest. & 283.968 & 4951 \\
\hline 6F & May 21-26, 2015 & 10.7 & Gest. & 148.817 & 3671 \\
\hline 7F & May 17-25, 2016 & 8.8 & nulliparous & 1342.068 & 3356 \\
\hline 8F & July 01-08, 2012 & 11.0 & Postl. & 23.006 & 2987 \\
\hline 9F & July 16-27, 2013 & 11.2 & Postl. & 498.384 & 2916 \\
\hline 10F & July 11-19,2014 & 11.5 & Postl. & 219.566 & 6136 \\
\hline 11F & July 21-27, 2015 & 11.3 & Postl. & 633.932 & 4417 \\
\hline 12F & July 08-20,2016 & 11.8 & Postl. & 824.893 & 929 \\
\hline 13F & July 09-21,2016 & 11.4 & Postl. & 83.183 & 3777 \\
\hline 14F & July 12-22, 2016 & 11.7 & Postl. & 206.405 & 5723 \\
\hline 15F & July 09-17, 2017 & 11.8 & Lact. & 1005.407 & 3030 \\
\hline 16F & July 08-18, 2018 & 12.2 & Lact. & 217.680 & \\
\hline
\end{tabular}

in the foraging sites of the tagged bats. The signals were recorded with a Zoom H2 Handy Recorder (Zoom Corp., Japan) in WAV format at a sample rate of $44.1 \mathrm{kHz}$ and a bit depth of 16 bit. Processing and analysis were carried out with BatSound 3.31 software (Pettersson Elektronik $\mathrm{AB}$, Sweden). At the same time, visual observations and recording of total nocturnal activity of E. nilssonii species in their main hunting areas were carried out (Tab. 2) (Smirnov \& Vekhnik, 2011b).

Foraging sites (habitats) were defined as spaces where bats exhibited nocturnal activity for at least five-minutes. Areas with less than five minutes of activity were classified as transit sites (Smirnov et al., 2017c). Such classification was carried out in order to distinguish the territories where animals stayed longer and clearly showed foraging activity from the areas characterized by extremely short stay, inhabited during travel flight, appearing a priori unattractive for hunting, and lack of foraging activity. The sizes of bat foraging habitats were determined by their extreme location points, with 10 to $200 \mathrm{~m}$ measurement error and up to $5 \mathrm{~m}$ by visual observation depending on the distance. The total habitat for each individual was estimated by extreme points of all its foraging habitats, including transit areas. Total tracking time for all females amounted 3480 hours.

The five types foraging habitats used by bats were identified within the home range: areas beneath forest canopies, clearings along forest edges, above-water areas near the riverbank, above-water area in the middle of the riverbed (far from the riverbank), and the territory of the populated place.

Nocturnal activity and habitat use in E. nilssonii individuals was tracked every night in period of observations (Tab. 2). The period of nocturnal activity was estimated relative to the night duration from sunset to sunrise (calculated for $\mathrm{N} 53.432^{\circ}$, E $49.925^{\circ}$ coordinates), and from the evening emergence from the daytime roost until their return thereto. All colony members leaving and returning to the roost were registered with camera traps continuously recording roosting holes.

Data analysis - To analyze foraging time and presence in the main foraging habitats, we used relative values calculated as the percentage of total time of nocturnal activity that was spent in a particular foraging habitat.

To study seasonal differences, we divided all observations into two periods: the prenatal period (May) and

Table 2. Number of observations (nights) of Eptesicus nilssonii performed to detect different types of activity.

\begin{tabular}{|c|l|c|c|c|c|}
\hline & \multicolumn{1}{|c|}{ Type of activity } & Gest. & Lact. & Postl. & Total \\
\hline 1 & Nocturnal activity at the roost (radio-tracking) & 28 & 20 & 59 & 107 \\
\hline 2 & Nocturnal activity at the roost (camera traps) & - & - & - & 129 \\
\hline 3 & Hunting behaviour (radio-tracking) & 28 & 20 & 60 & 108 \\
\hline 4 & Hunting behaviour (ultrasound detection) & - & - & - & 224 \\
\hline 5 & Home ranges (radio-tracking) & 28 & 20 & 71 & 119 \\
\hline 6 & Habitat selection (radio-tracking) & 28 & 20 & 71 & 119 \\
\hline 7 & Habitat use (ultrasound detection) & - & - & - & 224 \\
\hline
\end{tabular}


the postnatal period (July). Both lactating and post-lactating females were observed during the second period. However, because the former were predominantly in late lactation and showed behavior similar to the latter, with few exceptions, they were considered together when analyzing the calculation of habitats and the nature of their use.

Statistical analysis was carried out with Statistica for Windows ver.6.0. Since some data was not normally distributed, we used median values (Me), percentiles $(25 \%$, $75 \%$ ), and $\mathrm{min} / \mathrm{max}$ indicators for their description. The Mann-Whitney $U$-test was used to assess the differences, and the Spearman's rank correlation coefficient $\left(R_{\mathrm{sp}}\right)$ with a threshold significance level of $p<0.05$ was used to determine correlations.

\section{Results}

Daytime roosts - In Samarskaya Luka, E. nilssonii settles exclusively in trees $(n=57)$. The largest number of roosting sites $(90.4 \%)$ were detected in hollows with slitlike entrance holes in lindens (Tilia cordata); there were significantly fewer roosts in maples (Acer platanoides) and oaks (Quercus robur). A single colony was observed in a maple hollow with a circular entrance. Roosts were found 3 to $10 \mathrm{~m}$ above the ground. The surrounding biotope was middle-aged maple-linden forest with almost closed canopies and varying degrees of undergrowth development. The roosting distance from the river ranged from 0.4 to $3.1 \mathrm{~km}$. During the observation period, the bats switched their roosts every 1-4 days, reusing some of them. This behavior was characteristic for pregnant and post-lactating female colonies, while lactating individuals remained in the same root for almost the entire period of lactation.

Time budget and nocturnal activity - Nocturnal activity in female E. nilssonii accounted for $1.1 \%$ to $9.8 \%$ of total daily time and $8.8 \%$ to $76.9 \%$ of night time, ranging from 40 minutes to 5 hours (Fig. 1). In pregnant and postlactating females, the duration of nocturnal activity was nearly the same $(U=75.0, Z=0.70, p=0.487)$ and accounted for $(\mathrm{Me}) 44.7 \%(34.4,60.8)-3$ hours 05 minutes and $40.6 \%(27.4,54.4)-3$ hours 15 minutes of night time, respectively. Lactating females showed significantly less activity. They spent $23.1 \%(16.4,40.1)-1$ hour 45 minutes of night time outside their daytime roost, which is statistically different from the activity time of pregnant females $(U=47.0, Z=2.0, p=0.042)$ and post-lactating $(U=21.0, Z=2.2, p=0.031)$ females.

Evening emergence from the roost in May and July began at approximately the same time on average 35-45 minutes after sunset. The emergence time was strongly dependent on sunset $\left(R_{\mathrm{sp}}=0.956, p<0.001\right)$ and weather conditions. For example, on a cloudy day, the flight was shifted earlier, and with a strong wind, it occurred later. The temperature regime had a significant effect. In July, foraging flight was observed every evening. In May, foraging activity was only recorded at air temperatures above $5-7^{\circ} \mathrm{C}$; bats stayed in hollows at lower temperature values.

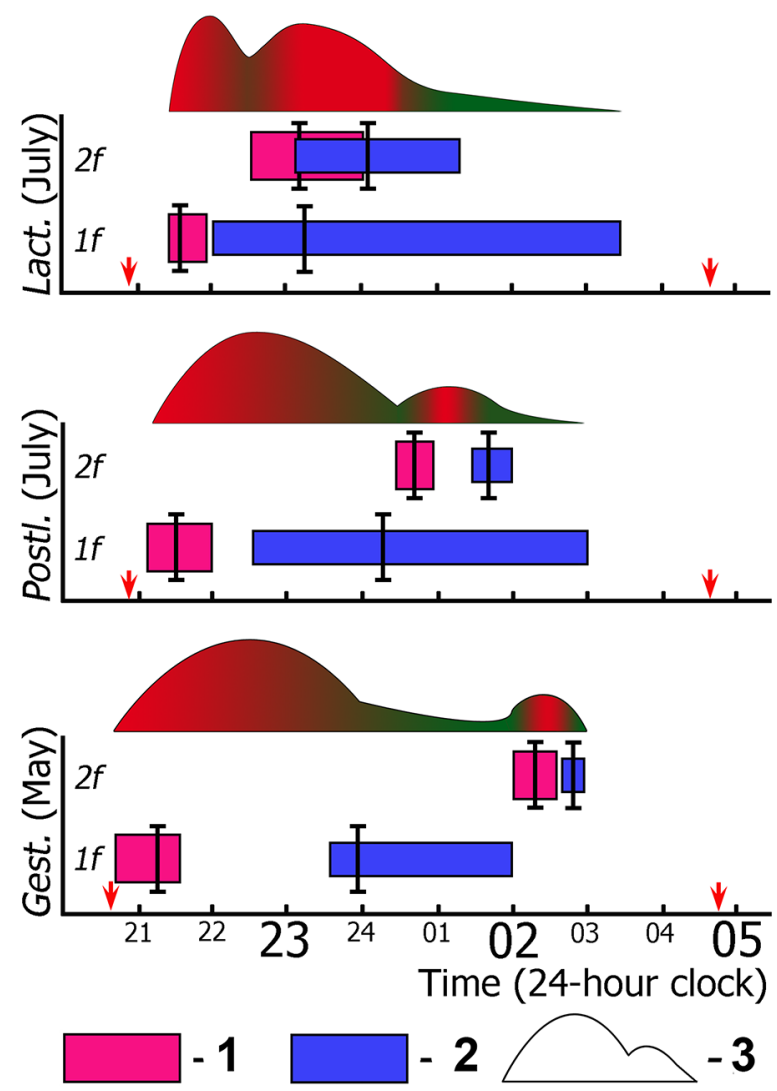

Fig. 1. Daily activity in lactating (Lact.), post-lactating (Postl.) and pregnant (Gest.) females Eptesicus nilssonii in May and July: 1 - the time of emergence from the roost, 2 - the time of return to the roost, 3 - duration and dynamics of nocturnal activity, $1 f$ and $2 f$ are the first and second phases of nocturnal activity, vertical lines are mean values for activity indicators. Arrows indicate sunset and sunrise $( \pm 10 \mathrm{~min})$.

In most cases (93\%), the bats hunted for 10 to 20 minutes immediately after emergence, flying exclusively beneath the forest canopy. Later, they migrated to more open spaces and primary foraging habitats, often located near the Volga River. Migration of bats occurred along the same routes between foraging habitats and roosts in $85 \%$ of cases.

The peak of E. nilssonii activity was observed in the period from 70 to 130 minutes after sunset. The species activity decreased significantly in the main foraging habitats after 24:00 once individuals returned to their roosts. In May, the bats began to show up in the roost at 23:30, and by midnight almost all bats had returned to the hollows. In July, most individuals returned from $24: 00$ to $00: 30$, and the earliest return of lactating females was recorded from 22:30 to 23:00. Some individuals then made another flight after returning to the roost. In May, short repeated activity was observed just before dawn, and the interval between the first and second flights was about five hours. In mid-summer, the second flight occurred earlier and extended for almost 

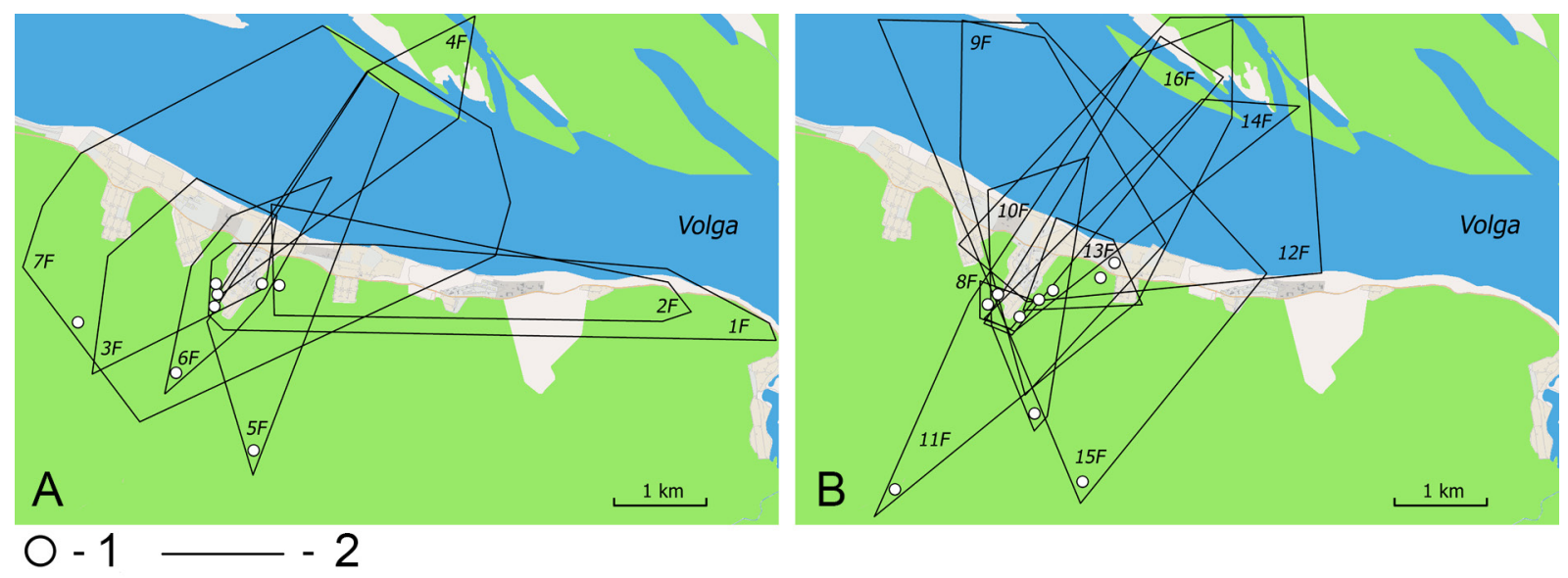

Fig. 2. Home ranges of 16 Eptesicus nilssonii bats in May (A) and July (B): 1 - locations of daytime roosts; 2 - boundaries of home range polygons.

two hours. Having returned after the first flight, postlactating females made another flight after midnight and returned to the roost by 02:00. The interval between the first and second flight phases was about three hours. In lactating females, the time between the first and second flights was even shorter and averaged two hours. Some individuals, especially lactating females, made several repeated flights.

Home range and habitat use - Home range sizes of females did not differ in spring and summer $(U=21.0$, $Z=0.75, p=0.452$ ) and averaged 430.7 and 401.8 ha, respectively (Tab. 1). Their location in relation to daytime roosts was directed towards the river channel (Fig. 2).

Five to eleven foraging sites were registered within the home ranges of the tracked bats. There were no differences in their quantity depending on the season $\left(\chi^{2}=7.9, d f=5\right.$, $p=0.16)$. The sizes of foraging sites varied depending on the types of hunting space. For example, along the riverside sites were long (up to $1 \mathrm{~km}$ ) but relatively narrow (up to $200 \mathrm{~m}$ ). They were limited to woody vegetation in forest clearings and at the edges, and by the degree of forest sparseness and relief structure beneath the canopy in deep forest. The most remote foraging sites were registered $6 \mathrm{~km}$ away from the roosts on the opposite bank of the Volga River (Tab. 1, Fig. 2). The maximum distance from the roosts was usually registered between 1 hour 40 minutes and 2 hours 50 minutes after sunset with a nocturnal activity peak of the species.

Seasonal differences in the time spent by females in the main hunting areas have not been identified (Fig. 3). Maximum nocturnal activity of bats was spent hunting in forest edges and in the above-water areas along the riverside in both May and July. The animals spent almost half as much time on foraging beneath forest canopies. Minimal activity was recorded in the middle of the Volga riverbed and in the inhabited localities.

Bat activity duration in foraging habitats located at different distance from the roosts varied significantly in May and July. In late spring, they hunted mainly over $3 \mathrm{~km}$ away from daytime roosts, while in summer bats rarely foraged at such a long distance $(U=6.0, Z=4.8$, $p<0.001)$. In July, on the contrary, nocturnal activity was concentrated in foraging sites within $1 \mathrm{~km}$ from the roosts $(U=82.0, Z=-2.5, p=0.012)$, and bats seldom flew away up to $3 \mathrm{~km}$ (Fig. 4).

Intraspecific and interspecific interactions Registration of $E$. nilssonii joint hunting with conspecific individuals was conducted at the sites of their greatest activity at twilight when it was easy to observe and detect the tagged bats. This observation period amounted to $70 \%$ of the total nocturnal activity time.

Species tagged by a radio transmitter fed mainly alone $(75 \%)$, while those in groups distanced themselves most of the time (92-98\%) from other individuals. A few intraspecific contacts were observed, mainly at the beginning of nocturnal activity (67-80\%), when females hunted near their roosts. When sharing the same habitats, especially densely populated ones, conspecifics

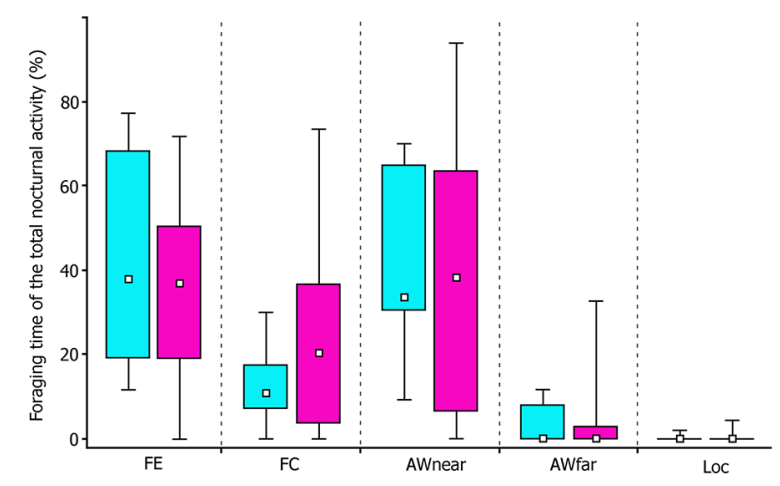

Fig. 3. Foraging time in Eptesicus nilssonii in the north of Samarskaya Luka in May (blue) and July (pink) for five main types of hunting spaces in nocturnal activity: FE - is forest edge, $\mathrm{FC}$ - are areas beneath the forest canopy, AWnear — are above-water areas near the riverbank, AWfar - are abovewater areas far away from the riverbank, Loc - is an inhabited locality. Values are visualized as median (square), percentiles (rectangle), and min and max (vertical line) indicators. 


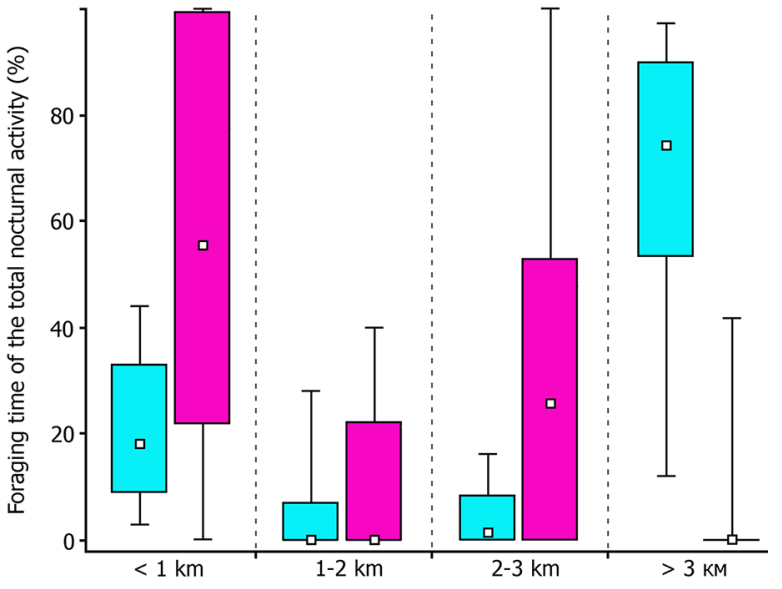

Fig. 4. Activity patterns in Eptesicus nilssonii in foraging habitats in the north of Samarskaya Luka in May (blue) and July (pink), based on distance from the daytime roost. Values are visualized as median (square), percentiles (rectangle), and min and max (vertical line) indicators.

chased each other for less than seven seconds or made high intensity calls. We registered 57 territorial conflicts during the whole observation period. Intraspecific interactions were observed more often in pregnant bats ( 0.12 contacts of the individual per day) than in postlactating (0.08) and lactating (0.09) ones.

Interspecific interactions were observed much less frequently (18 cases). They occurred more often (66\%) in semi-cluttered and side-cluttered spaces, namely forest clearings, along forest edges, and forested riverside. In other cases (34\%) they occurred in cluttered and uncluttered habitat types. Such interactions were recorded with Nyctalus noctula (Schreber, 1774), Myotis brandtii (Eversmann, 1845), M. mystacinus (Kuhl, 1817), M. daubentonii (Kuhl, 1817), Pipistrellus nathusii (Keyserling \& Blasius, 1839) and E. serotinus (Schreber, 1774). Usually, E. nilssonii avoided contacts with other bat species, and quickly retreated upon meeting them, flying to other territories (63\%). We have not registered any explicit aggressive interactions.

\section{Discussion}

Samarskaya Luka is the southern limit of E. nilssonii distribution in the European part of Russia. Due to various natural conditions (mountainous relief, karst, mixed and deciduous forests, broad floodplain of the Volga River), the highest species population density and the largest hibernation occur there, with 600 to 1000 wintering bats recorded annually (Smirnov et al., 2007, 2017a; Smirnov \& Vekhnik, 2011a). Relative abundance in summer captures (excluding data on caves) ranges from 6.6 to $18.5 \%$ in different years $(n=14)$ (Smirnov \& Vekhnik, 2012; our unpublished data). Abundance in Samarskya Luka is much higher than in the Cis-Urals, the Southern and Middle Urals (Ilyin et al., 2002b, Pervushina, 2006; Snitko \& Snitko, 2017a), the Middle
Trans-Urals (Pervushina \& Pervushin, 2015), and even the Chelyabinsk region with the greatest abundance of this species (Snitko \& Snitko, 2017b).

In Samarskaya Luka, tree hollows are the main summer roosts for E. nilssonii. Moreover, it is known that the species prefers to roost in human settlements (Kuzyakin, 1950; Novikov et al., 1970; Rydell, 1989, 1993b; Pervushina, 2006; Snitko \& Snitko, 2015). We examined over 300 buildings in searching for bats; however, we failed to find $E$. nilssonii in such places.

We did not observe strict preference for the same hollows in bats of this species. Actual reasons for frequent roost switching are not clear, but may include distance to foraging sites, human intervention, changes in roost microclimate and structure, and predation and parasite pressure (Lewis, 1995, 1996; Kerth et al., 2001; Sedgeley, 2001; Speakman \& Thomas, 2003; Willis, 2006). In our opinion, the first reason is unlikely because all discovered daytime roosts were located near forest edges, which were the main foraging sites. After leaving the roost, the bats always foraged along forest clearings and edges and then shifted to the riverside area. We suggest that anxiety and parasite exposure cannot be key factors either. We examined all caught animals for ectoparasitic infection. In E. nilssonii it was several times lower than in other species. Often there were individuals on whose bodies no parasites were found. Only tagging with a transmitter could cause discomfort and anxiety in animals; however, we did not notice a resulting significant change in behavior. The tagged bats returned to their colonies and shifted roosts. Video recording with camera traps showed that the behavior characteristics concerning time and intensity of evening departure and return to the hollow varied little.

In E. nilssonii, like in other bat species (Smirnov, 2013), evening emergence to hunt is highly dependent on the sunset time, which indicates light level as a signal for emergence from the roosts (Erkert, 1982). On average, animals flew out within 40 minutes after the onset of twilight. Obviously, this is a crucial time to reduce the risk of attack by birds of prey (Schaefer, 1974; Obuch, 1989; Rydell, 1992a). The use of forest areas can significantly increase predator avoidance; after leaving their roosts, the bats flew for some time beneath the nearby forest canopy, where light is lower than in open areas. This behavior is normal, and foraging lasted up to 40 minutes beneath the canopy (Rydell, 1986a, b).

Bat activity peaks in the first half of night (Smirnov, 2013, this study) and is associated with the number of insects (Swift, 1980; Barclay 1982; Hayes, 1997; Smirnov, 2018), regardless of female bat reproductive status. However, in our study, the activity duration slightly differed among females of different reproductive status. After an evening flight, lactating individuals foraged on average less time than pregnant and postlactating females not caring for offspring (Fig. 1). Because females are strongly linked to the maternity roost to regularly feed their non-flying offspring (Swift, 1980; Maier, 1992; Henry et al., 2002), they are forced to return after a short time interval. Subsequent flights 
may be short, and their number is obviously specific to each individual.

The second phase of nocturnal activity is typical for this species. As already mentioned, it is most common in lactating females. The increased energy demand from milk production (Kunz, 1987; Kurta et al., 1987, 1989; Wilde et al., 1995) should naturally lead to an increase in the total foraging time (Rydell, 1993; de Jong, 1994). However, in our studies, lactating females had in average less foraging time than pregnant and post-lactating females, and their activity was aimed at increasing the number of foraging tours. The second flight occurs less frequently in post-lactating females, since they have an increase in activity duration and, as we assume, higher foraging efficiency during the hunt. In addition, it is common for individuals to rest at the end of the first phase in temporary shelters, often located a considerable distance from their main roosts, instead of returning. We repeatedly recorded such cases $(n=7)$. In May, the ambient temperature drops sharply after twilight (http:// www.pogodaiklimat.ru/archive.php), the number of insects is greatly reduced, and hunting becomes energyintensive (Rydell, 1989). Repeated flights are very rare in pregnant females in May; if it occurs, it is shifted to later time and has duration comparable to that of postlactating females in July. Lack of foraged resources can lead to torpor in animals that have returned to the roost, and with prolonged critical temperatures $\left(5-7^{\circ} \mathrm{C}\right)$, this state can continue until normal temperature values (Rydell, 1989; Haupt et al., 2006).

In summer habitats, the nature of bat distribution depends on foraging resources (Bradbury \& Vehrencamp, 1976; de Jong, 1994; Sokolova \& Smirnov, 2019). In Samarskaya Luka, E. nilssonii showed the highest activity along forest edges and water bodies. Particular preference was given to riverside areas, as they provide the greatest abundance of insects, including swarming ones without tympanal organs that are easy to catch (Rydell, 1986a; Jaberg \& Blant, 2003). These territories are also attractive because of optimal and more stable temperature regime (de Jong, 1994). At night, the temperature significantly decreases over onshore, which affects the activity and amount of insects, but is stable in the above-water areas. This is especially relevant in the spring when night temperature drops to critical values. However, some studies have shown (Rydell, 1993b) that bats use the riverside territories primarily in summer and fly to anthropogenic environments with artificial lighting in spring and autumn. In Germany, for example, female $E$. nilssonii use the space around street lamps as foraging sites immediately after giving birth rather than before (Haupt et al., 2006). This is due to luminous lights attracting a large number of insects (Rydell, 1992b; Blake et al., 1994; Rydell \& Racey, 1995) and, therefore, significantly simplifying hunting, especially for lactating females with greatest energy costs. In our studies, females of different reproductive status foraging near street lamps was an exception rather than the rule. The bats only used the illuminated areas of inhabited localities as transit areas and did not linger.
Despite the existing view (de Jong, 1994; Henry et al., 2002), in our study the sizes of home ranges of females at different stages of the reproductive cycle did not have significant differences. At the same time, they were much larger than the home ranges (almost 40 times) that had been established between May and July for this species in earlier works (de Jong, 1994; Henry et al., 2002). This discrepancy is difficult to explain, but, in our opinion, it may be related to regional peculiarities of distribution within the home range of the main feeding areas.

We suggest that foraging sites size depends not only on the type of hunting space, but also on the abundance of forage resources (Rydell, 1993b). Foraging sites with abundant forages were usually smaller. We identified this feature mainly in forest clearings and along forest edges (Smirnov, 2018). Over open treeless land areas with a lower forage density, such areas were quite extended. An exception were the coastal near-water areas, in which $E$. nilssonii fed in a fine-grained manner. The abundance of food in this case was quite high, however, during the nighttime activity, the bats did not give preference to any specific food spot in the environmental mosaic, but exploited a relatively large territory evenly.

The intensity of foraging site use, located at different distance from the roosts, varies during the warm season. In spring, females expand their search for foraging sites and spend much more time in habitats located over $3 \mathrm{~km}$ away from the main roosts. In summer, the nature of activity in different areas changes, and females prefer to hunt closer to their roosts. Such seasonal differentiation allows them to maximize food intake, which is especially important during lactation. By staying close to their main roosts in summer, lactating females avoid unnecessary energy costs from flying to more remote foraging places. This shift in foraging distance is also facilitated by increase in biomass of available insects between the May pregnancy and July lactation periods (Anthony \& Kunz, 1977; Racey \& Swift, 1985). Studies by de Jong (1994) show that as long as insect abundance is high, the bats hunt very close to the colony. Increase in insect availability may also explain why lactating females, with greater food requirements, do not increase the time allocated to flight (Kurta et al., 1989).

Intraspecific and interspecific contacts can affect fidelity time of individuals in foraging sites. For example, research in territorial behavior of $E$. nilssonii conducted in Sweden revealed rank distribution in individuals protecting their territories (Rydell, 1986b, 1989). As shown by the author of these works, the initiators of such interactions are always dominant individuals, attacking others until they leave the territory. As a rule, foraging sites were protected by all categories of residents except for young and higher rank individuals. Since the number of aggressive contacts increases with a high density of conspecifics, the time of foraging site use for low-ranking individuals may be reduced. Interspecific contacts also sometimes reduce time spent in foraging. Despite confirmed absence of obviously aggressive interactions (Rydell, 1986a; Haupt et al., 2006), the bats immediately left the territory as nonconspecifics appeared, and rarely foraged jointly, such as when the 
other species was represented by single individuals. The abundance of forage resources and a different foraging strategy could reduce their competition in such situations (Smirnov, 2018).

\section{Conclusion}

In Samarskaya Luka, adult female E. nilssonii at different stages of the reproductive cycle are characterized by various behavior models and time budgeting. There are obvious differences in duration of nocturnal activity, time used by bats in various hunting territories, and their location regarding their daytime roosts. Regardless of the season, the main foraging sites for females are forest edges, clearings and spaces along vertical tree and shrubbery vegetation of the riverbank area. They regularly use the same foraging sites for a long time. In late spring, despite relatively similar home range sizes, pregnant females often search for food and hunt in places located over $3 \mathrm{~km}$ away from daytime roosts. With the abundance of forage resources in summer, lactating and post-lactating females usually forage within $1 \mathrm{~km}$ of their roosts. Emergence time for hunting depends on the time of sunset and the light level. The intensity of satiety is probably a determining factor influencing duration of nocturnal activity and is the same in pregnant and post-lactating females not caring for offspring. During lactation, duration of multiphase foraging activity decreases in females, as they often return to the roost to feed non-flying juveniles. In spring, when ambient temperature drops below critical values and forage abundance sharply decreases, pregnant females can reduce energy costs by ceasing nocturnal activity and becoming torpid.

ACKNOWLEDGMENTS. The authors are grateful to Vladimir Vekhnik, researcher of Zhigulevsky Nature Reserve, and $\mathrm{PhD}$ students Farid Baishev and Anton Lukyanenko for their assistance in field research. We are grateful to Johnny de Jong for his valuable comments for the first draft.

\section{References}

Aldridge H.D.J.N. \& Brigham R.M. 1988. Load carrying and maneuverability in an insectivorous bat: a test of the $5 \%$ 'rule' of radiotelemetry // Journal of Mammalogy. Vol.69. P.379-382.

Allyson L.W. \& Harris S. 1996. Foraging habitat preferences of vespertilionid bats in Britain // Journal of Applied Ecology. Vol.33. P.508-518

Anthony E.LP. \& Kunz T.H. 1977. Feeding strategies of the little brown bat, Myotis lucifugus, in southern New Hampshire // Ecology. Vol.58. P.775-786.

Barclay R.M.R. 1982. Night roosting behavior of the little brown bat, Myotis lucifugus // Journal of Mammalogy Vol.63. P.464-474.

Barclay R.M.R. 1989. The effect of reproductive condition on the foraging behavior of female hoary bats, Lasiurus cinereus // Behavioral Ecology and Sociobiology. Vol.24. P.31-37.

Blake D., Hutson A.M., Racey P.A., Rydell J. \& Speakman J.R. 1994. Use of lamplit roads by foraging bats in southern England // Journal of Zoology. Vol.234. P.453-462.

Bradbury J.W. \& Vehrencamp S.L. 1976. Social organization and foraging in emballonurid bats. I. Field studies // Behavioral Ecology and Sociobiology. Vol.1. P.337-381.

Burt W.H. 1943. Territoriality and home range concepts as applied to mammals // Journal of Mammalogy. Vol.24. P.346-352.

Catto C.M.C., Racey P.A. \& Stephenson P.J. 1995. Activity patterns of the serotine (Eptesicus serotinus) at a roost in southern England // Journal of Zoology. Vol.235. P.635-644.

de Jong J. 1994. Habitat use, home-range and activity pattern of the northern bat, Eptesicus nilssoni, in a hemi-boreal coniferous forest // Mammalia. Vol.58. P.535-548.

Dietz M. \& Kalko E. 2007. Reproduction affects flight activity in female and male Daubenton's bats, Myotis daubentonii // Canadian Journal of Zoology. Vol.85. P.653-664.

Erkert H.G. 1982. Ecological aspects of bat activity rhythms // Kunz T.H. (ed.). Ecology of Bats. New York \& London: Plenum Press. P.201-242.

Grinevitch L., Holroyd S.L. \& Barclay R.M.R. 1995. Sex differences in the use of daily torpor and foraging time by big brown bats (Eptesicus fuscus) during the reproductive season // Journal of Zoology. Vol.235. P.301-309.

Hayes J.P. 1997. Temporal variation in activity of bats and the design of echolocation studies // Journal of Mammalogy. Vol.78. P.514-524.

Hamilton W.J. \& Watt K.E.F. 1970. Refuging // Annual Review of Ecology and Systematics. Vol.1. P.263-286.

Haupt M., Menzler S. \& Schmidt S. 2006. Flexibility of habitat use in Eptesicus nilssonii: does the species profit from anthropogenically altered habitats? // Journal of Mammalogy. Vol.87. P.351-361.

Henry M., Thomas D.W., Vaudry R. \& Carrier M. 2002. Foraging distances and home range of pregnant and lactating little brown bats (Myotis lucifugus) // Journal of Mammalogy. Vol.83. P.767-774.

Jaberg C. \& Blant J.-D. 2003. Spatio-temporal utilisation of roosts by the particoloured bat Vespertilio murinus L., 1758 in Switzerland // Zeitschrift fur Saugetierkunde. Vol.68. P.341-350.

Jone G., Duverger P.L. \& Ransome R. D. 1995. Conservation biology of an endangered species: field study of the greater horseshoe bats // Racey P.A. \& Swift S.M. (eds.). Ecology, Evolution and Behavior of Bats. Symposia of the Zoological Society of London. Vol.67. P.309-324.

Ilyin V.Yu., Smirnov D.G., Krasilnikov D.B. \& Yanyaeva N.M. 2002a. [Materials for the Bats (Chiroptera) Inventory of European Russia and Adjacent Regions]. Penza: Penza State University. 64 p. [in Russian].

Ilyin V.Yu., Smirnov D.G. \& Yanyaeva N.M. 2002b. [To the fauna, distribution, and landscape confinement of bats (Chiroptera: Vespertilionidae) of the Southern Urals and adjacent territories] // Plecotus et al. No.5. P.63-80 [in Russian, with English summary].

Kerth G., Weissmann K. \& Konig B. 2001. Day-roost selection in female Bechstein's bats (Myotis bechsteinii): 
a field experiment to determine the influence of roost temperature // Oecologia. Vol.126. P.1-9.

Kunz T.H. 1973. Resource utilization: temporal and spatial components of bat activity in central Iowa // Journal of Mammalogy. Vol.54. P.14-32.

Kunz T.H. 1987. Post-natal growth and energetics of suckling bats // Fenton M.B., Racey P. \& Rayner J.M.V. (eds.). Recent Advances in the Study of Bats. Cambridge: Cambridge University Press. P.395-420.

Kurta A., Jonnson K.A. \& Kunz T.H. 1987. Oxygen consumption and body temperature of female little brown bats (Myotis lucifugus) under simulated roost conditions // Physiological Zoology. Vol.60. P.386-397.

Kurta A., Bell G.P, Nagy K.A. \& Kunz T.H. 1989. Energetics of pregnancy and lactation in free-ranging little brown bats (Myotis lucifugus) // Physiological Zoology. Vol.62. P.804-818.

Kusch J., Weber C., Idelberger S. \& Koob T. 2004. Foraging habitat preferences of bats in relation to food supply and spatial vegetation structures in a western European low mountain range forest // Folia Zoologica. Vol.53. No.2. P.113-128.

Kuzyakin A.P. 1950. [Bats]. Moscow: Sovetskaya Nauka. 444 p. [in Russian].

Lewis S.E. 1995. Roost fidelity of bats: a review // Journal of Mammalogy. Vol.76. P.481-496.

Lewis S.E. 1996. Low roost-site fidelity in pallid bats: associated factors and effect on group stability // Behavioral Ecology and Sociobiology. Vol.39. P.335-344.

McLean J.A. \& Speakman J.R. 1997. Non-nutritional maternal support in the brown long-eared bat (Plecotus auritus) // Animal Behaviour. Vol.54. P.1193-1204.

Maier C. 1992. Activity patterns of pipistrelle bats (Pipistrellus pipistrellus) in Oxfordshire // Journal of Zoology. Vol.228. P.69-80.

Montgomery R.A. \& Roloff G.J. 2013. Habitat Selection // Encyclopedia of Biodiversity. P.59-69.

Novikov G.A., Airapetyants A.E., Pukinsky Yu.B., Strelkov P.P. \& Timofeeva E.K. 1970. [Animals of the Leningrad Region (Fauna, Ecology and Practical Significance)]. Leningrad: Leningrad State University. 359 p. [in Russian].

Obuch J. 1989. Chiropteran thanatocenoses in rocky fissures // Hanak V., Horacek I. \& Gaisler J. (eds.). European Bat Research, 1987. Prague: Charles University Press. P.453.

Pervushina E.M. 2006. [Ecological Analysis of the Summer Population of Bats (Chiroptera, Vespertilionidae) of the Middle Urals]. Abstract of PhD Dissertation. Yekaterinburg: IPAE UB RAS. 25 p. [in Russian].

Pervushina E.M. \& Pervushin A.A. 2015. [Bats (Chiroptera, Vespertilionidae) of the plain Middle Trans-Urals] // [Fauna of the Urals and Siberia]. No.1. P.153-155 [in Russian, with English summary].

Racey P.A. 1973. Environmental factors affecting the length of gestation in heterothermic bats // Journal of Reproduction and Fertility. Vol.19. Supplement. P.175-189.

Racey P.A. \& Speakman J.R. 1987. The energy costs of pregnancy and lactation in heterothermic bats // Symposia of the Zoological Society of London. Vol.57. P.107-125.

Racey P.A. \& Swift S.M. 1981. Variations in gestation length in a colony of pipistrelle bats (Pipistrellus pipistrellus) from year to year // Journal of Reproduction and Fertility. Supplement. Vol.61. P.123-129.
Racey P.A. \& Swift S.M. 1985. Feeding ecology of Pipistrellus pipistrellus (Chiroptera: Vespertilionidae) during pregnancy and lactation. I. Foraging behavior // Journal of Animal Ecology. Vol.54. P.205-215.

Rydell J. 1986a. Foraging and diet of the northern bat Eptesicus nilssoni in Sweden // Holarctic Ecology. Vol.9. P.272-276.

Rydell J. 1986b. Feeding territoriality in female northern bats, Eptesicus nilssoni // Ethology. Vol.72. P.329-337.

Rydell J. 1989. Site fidelity in the northern bat (Eptesicus nilssoni) during pregnancy and lactation // Journal of Mammalogy. Vol.70. No.3. P.614-617.

Rydell J. 1992a. Occurrence of bats in northernmost Sweden $\left(65^{\circ} \mathrm{N}\right)$ and their feeding ecology in summer // Journal of Zoology. Vol.227. P.517-529.

Rydell J. 1992b. Exploitation of insects around streetlamps by bats in Sweden // Functional Ecology. Vol.6. P.744-750.

Rydell J. 1993a. Variation in foraging activity of aerial insectivorous bat during reproduction // Journal of Mammalogy. Vol.74. P.503-509.

Rydell J. 1993b. Eptesicus nilssonii // Mammalian Species. No.430. P.1-7.

Rydell J. \& Racey P.A. 1995. Street lamps and the feeding ecology of insectivorous bats // Symposia of the Zoological Society of London. Vol.67. P.291-307.

Schaefer H. 1974. Tausend Zweifarbfledermause (Vespertilio murinus L.) aus der Hohen Tatra-Nachweis an Unterkiefern// Zeitschrift fur Saugetierkunde. Vol.39. P.1-9.

Sedgeley J.A. 2001. Quality of cavity micro-climate as a factor influencing maternity roost selection by a tree-dwelling bat, Chalinolobus tuberculatus, in New Zealand // Journal of Applied Ecology. Vol.38. P.425-438.

Shiel C.B., Shiel R.E. \& Fairley J.S. 1999. Seasonal changes in the foraging behaviour of Leisler's bats (Nyctalus leisleri) in Ireland as revealed by radio-telemetry // Journal of Zoology. Vol.249. P.347-358.

Shultz S.M., Dunham A.E., Root K.V., Soucy S.L., Carroll S.D. \& Ginzburg L.V. 1999. Conservation Biology with RAMAS Ecolab. Sunderland, Massachusetts: Sinauer Associates. 216 p.

Smirnov D.G., Vekhnik V.P., Kurmaeva N.M., Schepelev A.A. \& Il'in V.Yu. 2007. Species structure and dynamics of bat communities (Chiroptera: Vespertilionidae) hibernating in artificial caves of Samara Luka// Biology Bulletin. Vol.34. No.5. P.507-516.

Smirnov D.G. \& Vekhnik V.P. 2011a. Abundance and community structure of bats (Chiroptera: Vespertilionidae) hibernating in artificial caves of Samarskaya Luka // Russian Journal of Ecology. Vol.42. No.1. P.71-79.

Smirnov D.G. \& Vekhnik V.P. 2011b. [Hunting space types in bat's community in Volga region] // [University Proceedings. Volga Region. Natural Sciences]. No.25. P.247-257 [in Russian, with English summary].

Smirnov D.G. \& Vekhnik V.P. 2012. [Biotopic structure of bats communities inhabiting flood plain ecosystems of the Samarskaya Luka] // Izvestiya of Samara Scientific Center of the Russian Academy of Sciences. Vol.14. No.1. P.177-180 [in Russian, with English summary].

Smirnov D.G. 2013. [Organization of bat communities and populations (Mammalia: Chiroptera) in the temperate continental climate of Russia]. Dissertation of Doctor of Science, Biology. Penza: Penza State University. 236 p. [in Russian]. 
Smirnov D.G., Vehnik V.P., Kurmaeva N.M. \& Baishev F.Z. 2013. [Foraging sites and shelters used by Eptesicus nilssonii in Samarskaya Luka] // University Proceedings. Volga Region. Natural Sciences. No.4 (4). P.69-75 [in Russian, with English summary].

Smirnov D.G., Vekhnik V.P., Kurmaeva N.M., Bezrukov V.A., Baishev F.Z., Protasova O.V., Usacheva E.A., Yalysheva E.G., Glukhova G.V., Dementieva A.V. \& Evdokimova A.A. 2017a. [The results of winter counts of bats (Chiroptera, Vespertilionidae) in the artificial dungeons of Samarskaya Luka for 2004-2016] // [Natural Heritage of Russia. Proceedings of International Scientific Conference on 100th Anniversary of the National Reserve Business and the Year of Ecology in Russia]. Penza: Penza State University. P.250-252 [in Russian].

Smirnov D.G., Kurmaeva N.M. \& Ivanitsky A.N. 2017b. [To the study of bats (Chiroptera) of the Eastern Crimea] // Plecotus et al. No.20. P.17-29 [in Russian, with English summary].

Smirnov D.G., Bezrukov V.A. \& Ilyin V.Yu. 2017c. [The utilization of habitable space and forage time by Myotis daubentonii (Chiroptera, Vespertilionidae) in the Samarskaya Luka] // University Proceedings. Volga Region. Natural Sciences. No.4 (20). P.5-19 [in Russian, with English summary].

Smirnov D.G. 2018. [Comparative trophic niche analysis of Pipistrellus nathusii and Eptesicus nilssonii (Chiroptera, Vespertilionidae) in conditions of Samarskaya Luka] // University Proceedings. Volga Region. Natural Sciences. No.4 (24). P.28-41 [in Russian, with English summary].

Snitko V.P. \& Snitko L.V. 2015. [On the ecology of the northern bat (Eptesicus nilssonii, Chiroptera, Vespertillionidae) in the Southern Urals (Ilmensky Reserve, Chelyabinsk Region)] // Zoologicheskii Zhurnal. Vol.94. No.11. P.1330-1337 [in Russian, with English summary].

Snitko V.P. \& Snitko L.V. 2017a. [New data on the distribution of bats (Chiroptera, Vespertilionidae) in the Orenburg Region] // Zoologicheskii Zhurnal. Vol.96. No.1. P.83-89 [in Russian, with English summary].

Snitko V.P. \& Snitko L.V. 2017b. [Bats (Chiroptera, Vespertilionidae) of the Southern Urals (Chelyabinsk Region)] // Zoologicheskii Zhurnal. Vol.96. No.3. P.320349 [in Russian, with English summary].

Sokolova I.V. \& Smirnov D.G. 2019. [Nutritional composition features of the noctule Nyctalus noctula (Chiroptera: Vespertilionidae) in the lower Volga delta] // Plecotus et al. No.21. P.59-68 [in Russian, with English summary].

Speakman J.R. \& Thomas D.W. 2003. Physiological ecology and energetics of bats // Kunz T.H. \& Fenton M.B. (eds.). Bat Ecology. Chicago: University of Chicago Press. P.430-492.

Swift S.M. 1980. Activity patterns of pipistrelle bats (Pipistrellus pipistrellus) in north-east Scotland // Journal of Zoology. Vol.190. P.285-295.

Wiens J.A. 2001. The landscape context of dispersion // Clobert J., Danchin E., Dhondt A.A. \& Nichols J.D. (eds.). Dispersal. Oxford: Oxford University Press. P.96-109.

Wilde C.J., Kerr M.A., Knight C.H. \& Racey P.A. 1995. Lactation in vespertilionid bats // Symposia of the Zoological Society of London. Vol.67. P.139-149.

Willis C.K.R. 2006. Daily heterothermy by temperate bats using natural roosts // Zubaid A., McCracken G.F., Kunz T.H. (eds.). Functional and Evolutionary Ecology of Bats. New York: Oxford University Press. P.38-55. 